\title{
Impact of British Raj on the Education System in India: The Process of Modernization in the Princely States of India - The case of Mohindra College, Patiala
}

Kanika Bansal

Chitkara School of Planning \& Architecture, Chitkara University, Punjab

Email: kanika.bansal@chitkara.edu.in

\section{ARTICLE INFORMATION}

Received: February 06, 2017

Revised: April 18, 2017

Accepted: May 24, 2017

Published online: July 03, 2017

Keywords:

Education Reforms; British Raj; East India Company; Christian Missionaries; Princely States; Patiala

\begin{abstract}
British rule is said to have been responsible for the modernization witnessed in the Indian civilization. The impact of this process was quiet evident from the changes adopted by the Indians in their life style, thinking processes, attires, food and education. Besides the advancements made in the spheres of roads, transports, postal services etc, their rule acted as a significant period of transition from the indigenous style of education to western education. The foundations were laid by the East India Company and the Christian Missionaries to employ Indians for administrative tasks as well as to serve their political, economical and colonial interests. Originally the access to education was limited to the royal families, as the British were of the opinion that Indians could become aware of their rights and positions and protest against their Raj posing a threat to the British establishment in India. Lord Curzon's efforts in the 20th century gave way to spread of higher education within the masses and channelized Indian education system. However the rulers of the Princely States in of India who were granted autonomy by the British to manage their own kingdoms acted as major agents to undertake the social and educational reforms within their territories. With the spread of education from elementary to higher levels, many new schools, universities and other institutions were developed during this period which are symbols of educational advancement as well as hold high architectural merit. Patiala, aprime princely state is a well known academic centre also important for its rich culture since the British Raj. Education in Patiala originated under the Maharajas with the opening of the school of languages in 1860A.D. With the introduction of Mahindra College (the first Degree College in a city) in 1870, became came an important educational centre. It was the only college between Delhi and Lahore for a long time that promoted contemporary higher learning in Northern India. The historic college building represents an aesthetic mix of regional interpretation of Indo-Saracenic style of architecture. Later on many educational institutes catering to medical facilities, sports education etc. was set up in this princely state. This paper is thus an attempt to explore the education reforms during the British Raj, the changes that happened and their triggers. It also brings out reforms initiated in Princely States specifically Patiala as a seat of learning and a detailed study of the Mohindra College, Patiala, that represents an excellent example of educational institutions developed during the 19th century. The present study was done as a part of an academic project undertaken during Masters of Architecture under the able guidance of Prof Kiran Joshi..
\end{abstract}

\section{Introduction}

The British Raj in India triggered the process of modernisation and was primarily responsible in the making of a liberated India free from the medieval traditions. With the aim to govern the entire nation they brought about a uniform administrative system, improved modes of transportation and communication specifically by the introduction of rails, unified postal services and telegraphs. Several movements of the 19 century by eminent Indians against the atrocities of the British rule too set off reforms leading to modernization and help abolish the social evils prevalent in India at that time.
India also witnessed a sea change in the system of education under the British (Bidwaikar, S. 1813). They replaced the indigenous schooling system with the education of the new state system. In addition they established a number of educational institutions of high academic and architectural merit. This spread of education awakened middle class that led to the national movement for independence.

\subsection{Education Reforms during the British Rule}

Prior to the advent of the British Rule in India, the Indigenous Education System comprised of elementary 
schools like pathshalas, Maktabs, the primary schools and Madarsa for higher education (Dhanani B., Aarti, 2012). Vedas served to be the basis of the ancient education system which was not in pace to the education all over the world. Islamic Empires continued the legacy by promoting Islamic education that aimed at spreading Islamic culture and religion during the middle ages before the advent of western education by Europeans to the colonial India. British came to India, merely as traders in the 17 th century after the fall of Muslim Empire occupying Pondicherry, Madras and Calcutta. They had two fold motives - East India Company traders and as religious agents to proliferate Christianity which led to the introduction of western education in India. However, as the British Parliament took charge over the government, the period witnessed a breakthrough in the development of Indian Education system.

\subsection{Education under the East India Company}

Trade and profit-making being the prime motives, not much interest was shown by the East India Company towards promoting education in India. The existing education system suffered as the East India Company denied grants to institutions. However a number of institutions were set up to train Indians as representatives to Company's law courtswho would acts as medians between the general public and the government. During the late $18^{\text {th }}$ century, some of the first Educational Institutes were

(1) The Calcutta Madrasa (1781), Calcutta by Warren Hastings primarily for imparting education in the field of Muslim law to educate Muslim men for courts of justice. (Fig.1)

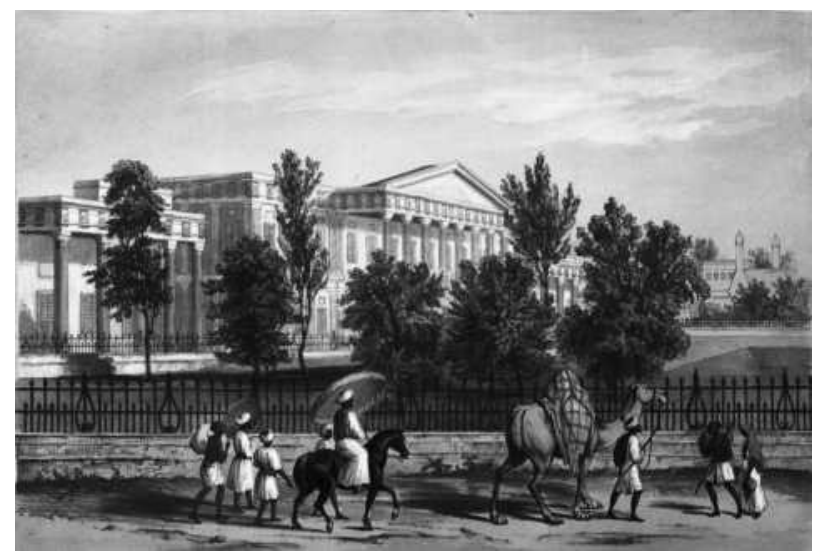

Figure 1. Plate 18b of Sir Charles D'Oyly's 'Views of Calcutta and its Environs' in 1848. (Source: https://puronokolkata.com/tag/ calcutta-madrasah)

(2) The Sanskrit College (1791)Benaras by Jonathan Duncan primarily with courses in the subject of Philosophy and Hindu Law. (Fig. 2)

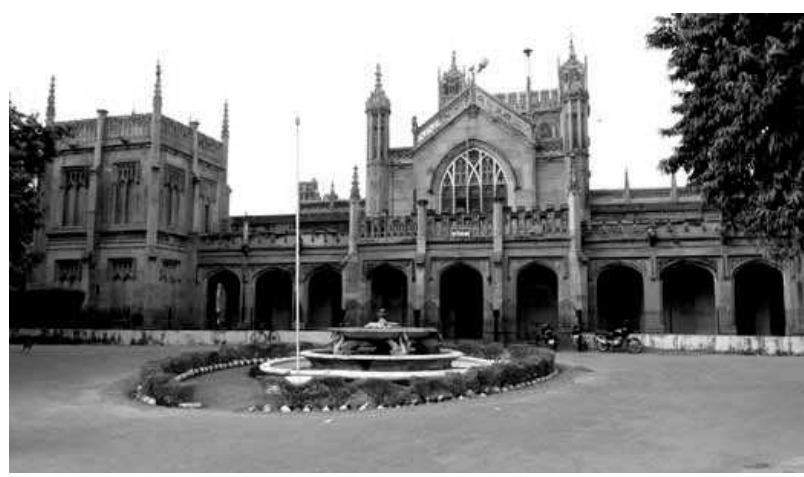

Figure 2. The Sanskrit College (1791) Benaras. (Source: https://www. hinduismtoday.com/modules/smartsection/item.php?itemid=5601)

(3) The Fort William College (1800), Calcutta by Lord Wellesley to produce Indians as Civil Servants trained in Indian Languages \& Customs to serve the Company. (Fig. 3)

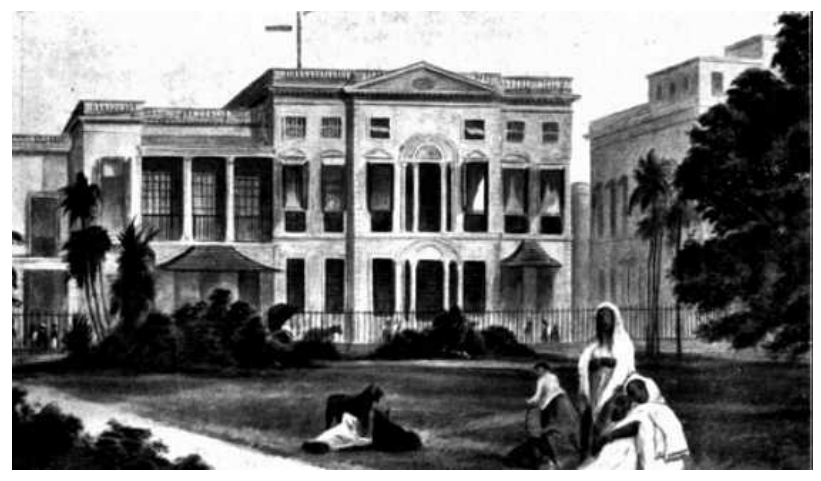

Figure 3. The Fort William College 1800. Calcutta . (Source: https://puronokolkata.com/2014/01/23/fort-w illiam-college-theexchange-calcutta-c1800)

\subsection{Education under the Christian Missionaries}

Englishmen from Europe came to India with the aim of destroying the prevailing religious faith amongst the Indians and to promote Christianity through their Christian Missionaries. They encouraged Western Education in India. Through Christian education the missionaries aimed in eradicating the anti social practices based on many superstitions that they considered uncivilized like polygamy, Idol worship, multiple god beliefs, etc. Charles Grant, an important Christian Missionary, contributed significantly in the renewal of the East India Company's Charter Act of 1813 (Cox, J. 2009). The articles added in the charter put responsibility on the East India Company to organize and expand education in their ruling empires. Although the act granted funds it however failed because, firstly the instruction imparting language was not laid down, secondly it was not clear that education was for all or only limited to a few and lastly the means of intensifying English Education in India 
indefinite. This gave rise to two Indian groups - ones who promoted classical languages as the medium of education known as Orientalists and the Anglicists who favoured English as medium of instruction. Raja Ram Mohan Roy, an educated Indian supported western education, justifying that this system of education would help eradicate the social, economic and politicalevils prevalent in India.

\subsection{Macaulay's Education System}

Introduced in 1835 by Lord Macaulay, also termed as "Lord Macaulay's Minute" then declared English language as the alone medium of Education in India as well as the court language replacing Persian as the prior court language. Free printing of English Books at low prices accelerated the use of English as a more acceptable medium in India. The system was implemented by setting up as many as forty two schools by the year 1842. Educational Zones were created having one government school each. Gradually by 1844 it was also made a mandate for the government officials to know English as a compulsory language and faded away the existing system of education. Thus English as a language became more popular and there was a switch in the traditional system of education to western education. As the British had mean intentions of not educating the common Indians because of the fear that the Indians would revoke to demand freedom from the British rule after receiving higher education, so they imparted education to only a few primarily males, in order to run the affairs of the Government. There was a complete neglect of the education for girls for to complement the orthodox beliefs of the Indians and also because females could not be hired for government jobs. Thus only 2\% women could attain the basic education upto as late as 1919 . This cropped the seed of development in education through the Downward Filtration Theory with the main intention of taking education to the common people instead of letting it be a Royals delight.

\subsection{Indian Education Commission 1882}

Mr. William Hunter appointed as the Indian Education Commision in 1882 by the then Viceroy, Lord Rippon introduced a check system on the medium and quality of the prevailing education systems. A more formal system of education with defined policies, curriculums, finances and the quality of teachers came into being ever since Hunter took charge. The commission recommended strategies to improve the standard of the primary institutions imparting indigenous, Secondary \& Higher Education. It also recommended appointments of Indians District inspectors of schools for quality check. Changes and reforms were introduced in the grant-in-aid system, free education for women, Harijans and Backward class.

\subsection{0th Century Reforms}

Educational reforms laid down by Lord Curzon from 1901-1904 gave a more guided perspective to the system of education in India by implementing rules and regulation to transform the haphazard system into an organized one. Thereafter, diarchy in the Indian provinces ended with the advent of the Government of India act, 1935. The All - India National Educational conference (Wardha Educational conference) in October 1937 held under the president of Gandhiji himself brought about significant reforms and was finally shaped up by the Vice Chancellor of JamiaMalia University, Dr. Zakir Hussain. This led to drafting of curriculum, principles, administration and management of the Wardha Scheme along with making handicrafts an integral part of the course curriculum.

\section{Education Systemin the Princely States of India - the British Policy of Educating the Royals}

East India Company's attempt to annex India into a British territory led to creation of two administrative systems Province \& Princely States. Provinces accounted for 60\% of the Indian Territory under the British Control and the remaining Princely States with Indian ruler of king who acted as agents of the British Empire. Inorder to continue reiningtheir kingdoms these rulers remained loyal to the British accepted to be under the British governance. As barter to this co-operation, the British gave autonomy to these 'Princely States' to manage the systems of education prevailing within their territories.(Fig. 4) Moreover, it was also expected that the class of educated Indians among these territories would promote education among the masses - as a part of the 'Downward Filtration Theory.' With the coming of The Wood's Despatch of 1854, a national education policy laid emphasis on spreading mass primary education, with the sole intention of creating a group of elites educated in English to be employed for administrative tasks It initiated the making of various departments in education within the princely states and gave guidelines to develop various levels of schools. Within these princely states, towards 1860 the transition in the schooling systems was witnessed with coming up of the government aided universities and their affiliated colleges along with a number of elementary, primary and secondary schools.

\subsection{Development of Institutions in the Princely States during the 19 Century}

The immediate outcome of the education reforms that prevailed during the British was the establishment of the 
male dominant educational system with English as universal medium of instruction language. The era saw a transition of Indians into well educated professionals which triggered the development of institutions in India. Each Princely State acted independently and administered the schools within the territories. The number of institutions rose rapidly from 4 universities \& 67 colleges educating 600 students in 1882 to 14 universities, 167 colleges, with 46,000 students in 1922. The Madras Medical College(1835) imparted education to women for the medical benefits to be given to female population who would otherwise feel shy in getting treated by male doctors. In 1857 Acts of Incorporation were passed for setting up affiliating universities in the three Presidency towns of Bombay, Calcutta and Madras establishing the University of Calcutta, Madras \& Bombay (Calcutta Madrasa, The 2017). The Women's Christian Medical College (1894), Ludhiana, Punjab was the first all women medical school that revolutionized in educating the women as medical professionals. The Government College University (1864), Lahore, and the Prestigious University of the Punjab (1882), The Muhammadan Anglo-Oriental College (MAO in 1875) or the 1920 National Muslim University at Aligarh was based on Oxford \& Cambridge University academic pattern with Islamic education integral to its curriculum. The Baroda University (1908), Baroda (Gujarat) renamed from Baroda College were some of the most significant university establishments during the British Raj. At the time of Independence, there were about 21 universities and 496 which conducted examinations for various degree courses.

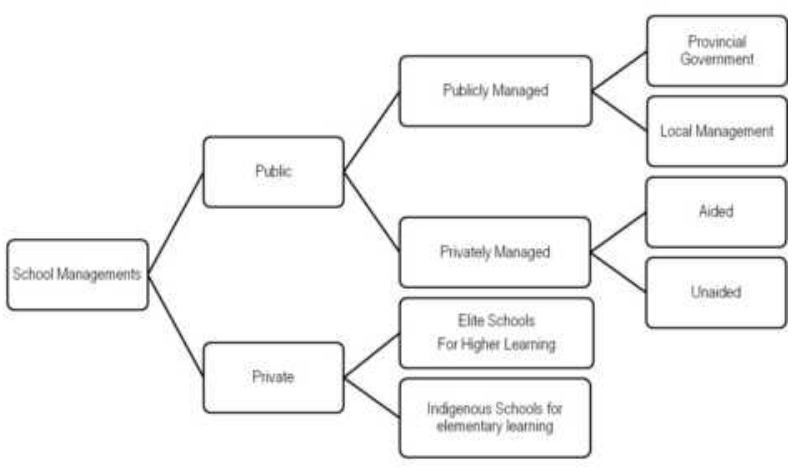

Figure 4. Hierarchical chart showing management of schools during British Raj. (Source: Author)

\subsection{Education advancements in the Princely State of Punjab during the British Rule}

With the introduction to new institutions and technologies during the British rule in Punjab the state advanced industrially and technologically adding to its economy. It came to be known as the best in agriculture because of the development of perennial canals, modern agricultural equipments and techniques and improved quality of seeds. As mechanically produced goods took over, works of traditional artisan faced downfall in their earnings which forced them to look for economic opportunities beyond the expanse of their community. This transformed the artisans professionally in two groups - skilled and unskilled labourers on construction sites. Large scale migration in hunt for work to the British colonies in western countries like South Asia, Africa and Latin America was witnessed. Some left behind opted to become professionals and took over the new education to become lawyers, teachers and engineers. Infact, education reforms became important as they led to change in occupation by a number of people. The colonial administration in the princely state of Patiala thus took the responsibility to educate the masses in English language as well as began to focus on imparting western knowledge. It aimed to bring out trained manpower to fulfil the technical, defence and administrative requirements of the colonial state with a focus on teaching of secular and literature course content. By mid 19 century, the motivated educated class in Punjab began to impart education through innovative programmes. 20 Century started to see the setting up of a number of educational institutions under the tutelage of the Islamic Anjumans, AryaSamajis and Singh Sabhas. Education was further extended to the private sector with the active involvement of the local municipalities in setting up of many institutions across the state.

While the Western education in the state was taking a leap, several advancements in the fileds of medicine and health were made evident from the establishment of hospitals for Soldiers and Europeans. The British were quite successful in setting up of various grades of civil hospitals and dispensaries along with the opening of a medical school at Lahore in 1860. Thereafter free elementary education was approved for boys and girls. The table summarizes the educational institutions developed in the 19th century in the region of Punjab(Fig. 5). Patiala is one such state revived by the British in 1808 when the ruler of Patiala along with the British stood against Ranjit Singh. This brought about changes in social structure and communal organisation after the British established modern education institutions and a capitalist economy. The Mohindra College, Patiala was one such attempt that showcased the British style of architecture.

\section{Educational infrastructure in Patiala}

Within the state of Punjab, educational facilities in Princely Patiala have significantly contributed in developing the state throughout (Priyadarshini S. 2017). In the educational 


\begin{tabular}{|c|c|c|c|}
\hline 1829 & DelhiEnglish Institution opened: closed in 1857 & 1875 & Govemment Mayo College of Art Lahore. \\
\hline 1834 & $\begin{array}{l}\text { American Prestyterian Lodiana [Ludhiana] Mission established. A school } \\
\text { established in } 1837 \text {. }\end{array}$ & $\begin{array}{c}1875 \mathrm{Mar} \\
30\end{array}$ & $\begin{array}{l}\text { Mohindra College Patala foundation stone laid Began as school } \\
\text { ftermediate classes added in } 1880 \text {; B.A. in } 1887 \text {. }\end{array}$ \\
\hline 1847 & Roorkee Engineering College opened, named after James Thomason in 1854 . & 1877 & Arya SamajLahore. \\
\hline $1849 \mathrm{Dec}$. & $\begin{array}{l}\text { Mission School opened in Lahore by the American Presbyterian missionary } \\
\text { Charles Wilsam Forman; shifted to the Rang Mahal palace in } 1853 \text {. }\end{array}$ & 1881Feb. 2 & The Tribune started at Lahore as a weekly. \\
\hline 1851 May & $\begin{array}{l}\text { Govemmentopens a school in Amritsar, subsequently handed over to the } \\
\text { American Mission. }\end{array}$ & 1882 Feb. 1 & $\begin{array}{l}\text { St Stephen's College Delhi established, Affiliated first to Calcutta University. } \\
\text { then to Punjab (1882) and finally to DelhiUniversity (1922) }\end{array}$ \\
\hline 1856 Jan. & Punjab Education department setup under Director of Public Instruction. & 1882 Oct 14 & Punjab Universily College made into a degree-awarding Punjab University. \\
\hline 1856 & $\begin{array}{l}\text { Randhir College Kapurthala (schoolto be gin with) established. Interme diate } \\
\text { classes introduced in } 1896 \text {, degree in } 1945 \text {. }\end{array}$ & 1882 & -ahore Veterinary School established. \\
\hline 1857 & $\begin{array}{l}\text { English Mission schools operational in Amritsar, Peshawar, Kangra, Kotgarh, } \\
\text { and Ferozepur Cantonment; American Mission schools in Lahore, Rawalpindi, } \\
\text { fullundur, Ludhiana, Ambala City. Ambala Cantonment, and Siakot. Most were } \\
\text { Govemment-aided. }\end{array}$ & $=1884$ Nov. 8 & Punjab Public Library Lahore estabilshed \\
\hline $1858 \mathrm{Feb}$. & The Dellhitenitory transferred from North West Province to Punjab & 1886 & Govemment College Lahore receives an annual library grant of Rs 200 . \\
\hline \begin{tabular}{|c|}
1860 Apr. \\
15
\end{tabular} & $\begin{array}{l}\text { GovernmentHigh School Lahore (Lahore District School) opened with L. C. } \\
\text { Beddy as head master }\end{array}$ & 1886 & Wission College Lahore opened; renamed Foman Christian College in 1894 \\
\hline 1860 Oct. & Medical School Lahore (made into College in 1886). & 1886 & Punjab Chief's Altchison College foundation stone laid. \\
\hline 1861 & Brahmo SamajLahore. & 1886 & $\begin{array}{l}\text { Dayanand Anglo-Vedic College Lahore (school department) established } \\
\text { (Jun. 1). Intemediate classes introduced in 1889; B.A, in 1894; MA. in } \\
\text { Sanskrit in } 1895 \text {. }\end{array}$ \\
\hline \begin{tabular}{|c|c|}
1864 Jan \\
15
\end{tabular} & $\begin{array}{l}\text { Govermment College Lahore established, with the principal G. W. Leitnertaking } \\
\text { charge in Nov. }\end{array}$ & 1889 & $\begin{array}{l}\text { Railway Technical School Lahore for Eurasian boys. INow part of } \\
\text { GovemmentCollege of TechnologyRailway RoadLahore.] }\end{array}$ \\
\hline |1864-1877 & $\begin{array}{l}7 \text { Govemment College Delhi. Closed on } 1 \text { April 1877: faculy and students } \\
\text { ransferred to Lahore. }\end{array}$ & 1892 & slamia College Lahore \\
\hline \begin{tabular}{|c|}
1865 Jan \\
21 \\
\end{tabular} & Anjuman-i-Punjab formed by Leitner & 1892 Mar. 5 & $\begin{array}{l}\text { Khalsa College Amritsar foundation stone laid. School began in } 1893 \text {. } \\
\text { College classes in May } 1897\end{array}$ \\
\hline $\mid 1866-1869$ & Rang Mahal Mission School Lahore runs College classes. & 1897 & $\begin{array}{l}\text { Victoria Diamond Jubilee Hindu Technical Institute Lahore established for } \\
\text { Hindu and Sikh boys. [Now part of Govemment College of Technology } \\
\text { RaihwayRoadLahore.] }\end{array}$ \\
\hline 1870 & $\begin{array}{l}\text { Punjab University College Lahore established underthe control of a Senate } \\
\text { Jan. 11). Oriental School (renamed Oriental College in 1872) and Law School } \\
\text { stablished. }\end{array}$ & 1910 & Pyal Singh College Lahore established. \\
\hline 1873 & Singh Sabha Amritsarformed. & & \\
\hline
\end{tabular}

Figure 5. Table drawing the timeline of development in Educational Infrastructure in Punjab. (Source: Author)

context, since the British rule, Patiala is well known as an education hub constituting large number of primary, middle secondary and senior secondary schools. (Fig. 6)

Patiala is one the first cities in Punjab toset up 'Mohindra College' in 1870's. The college happens to be the first degree college between Lahore and Delhiin northern India and boosts of being a top educational institute till date. Before Mohindra College, Kapurthala college had studies only upto the intermediate level. The closure of Ajmeri gate in Delhi in 1877 forced the students to take admission in the Mohindra College at Patiala. Students from Delhi started preferring to study at Mohindra College as the educational facilities provided here were more comparatively that time.

The first school of Patiala in 1860 taught Persian, Sanskrit, Arabic and Gurmukhi and expanded their teaching to English and Mathematics. However till this time Presian continued to be the most popular language amongst all. Maharaja Narinder Singh thereafterintroduced the State controlled education system in Patiala. In 1889 Maharaja
Rajendra Singh assigned his tutor to prepare the study codes of Patiala. Since then inspections of educational institutions started annually. Maharaja Bhupinder Singh in his early years started education in science and introduced education for girls. This reform promoted literacy amongst women which until 1901 was very low compared to literacy in men. 8 women out of 10,000 against 590men were literates till then.

The level of education continued to gain momentum in Patiala and was further set in accordance to the level of education in Punjab. In 1938 Arya High School, Patiala school and Hindu SewaSammiti School were registered by the government of Patiala. The education for girls was given due consideration so Victoria High School for girls was inaugurated. Under the reign of Maharaja Bhupinder Singh Punjabi was made as the government language and in 1910 he got the first state Gazetter published in Punjabi. He made primary education free for all in Patiala. With the efforts of Maharaja Yadavindra Singh, a girls' college was opened in Patiala. Primary education for all and girls education was 
made free. With the advent of PEPSU in 1948 and its growth till 1956 gave progress to the field of education in Patiala.

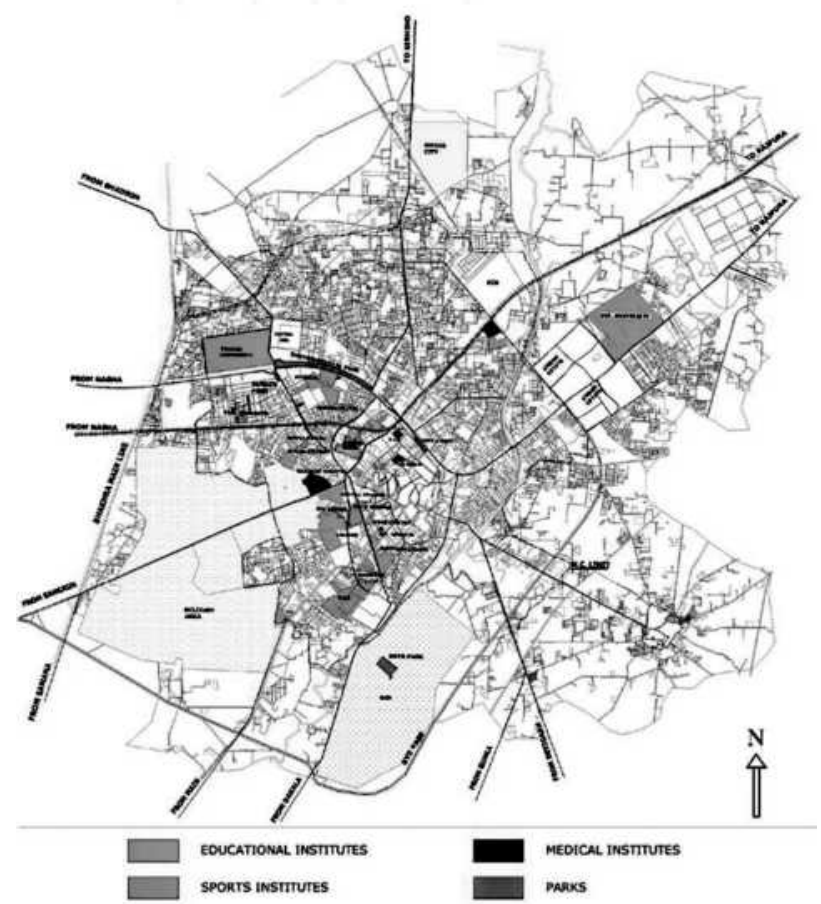

Figure 6. Map showing Educational, Medical, Sports, Institutes \& Parks - Patiala (Source : Map taken from Google Earth; Adapted by Author)

The development of medical institutions took a steep rise after India's independence in 1947 with the coming of Govt. Ayurvedic College in 1952 and the Govt. Medical College in 1953. The year 1956 saw the development of Thapar Institute of Engineering and Technology along with the development of Central State Library. The shifting of the Punjab Public Service Commission Headquarters from Shimla to Patiala 1957 was another remarkable achievement which progressed education in the city. Gradually with the setting up of National Institute of Sports in 1961, the Punjabi University in 1962and the National Law University, first of its kind in north in 2006 Patiala came to be recognized as important learning city nationally.

\subsection{History of Patiala}

The state Patiala is believed to date back to Vedic era, however, in 1763 Baba Ala Singh, a successor of the Phulkian family is credited with the development of the town after the fall of Sirhind who also laid the foundation of the QIla Mubarak (Punjab Govt. Lahore 1909). Bordered by rivers and thick and forests, the town was set up primarily as a military stronghold. It is a belief that Patiala derived its name from the term Pattan-wala, or by combining the words 'Pati' meaning 'territory', and 'Ala' dedicated to its founder Baba Ala Singh.

Patiala became a Princely State in the year 1808, when they signed a treaty with British Raj at Lahore as a revolt against the Maharaja Ranjit Singh. It became the capital of the of the independent Sikh state till the $20^{\text {th }}$ century and continued to be the capital of Patiala East Punjab State Union (PEPSU) thereafter. The autonomy developed under the British helped Patiala prosper gradually such that it became a prime centre for arts. in the of peace becoming a center for the arts. Between 1845 and 1862, Patiala became a walled city when Maharaja Narendrafortified it with ramparts.(Fig. 7) This walled city became the nucleus of growth of the city of Patiala beginning from the Qila Mubarak within the walled city from where the city is said to have originated and then grew radially along its edges with time (Geddes P., 1973). Further on, the contribution of Maharaja Bhupinder Singh in early 20th century helped in giving political recognition to Patiala as a centre for promoting international sports. He also is accredited with getting architecturally splendid buildings built which gave city the title of being the most beautiful city in Punjab.

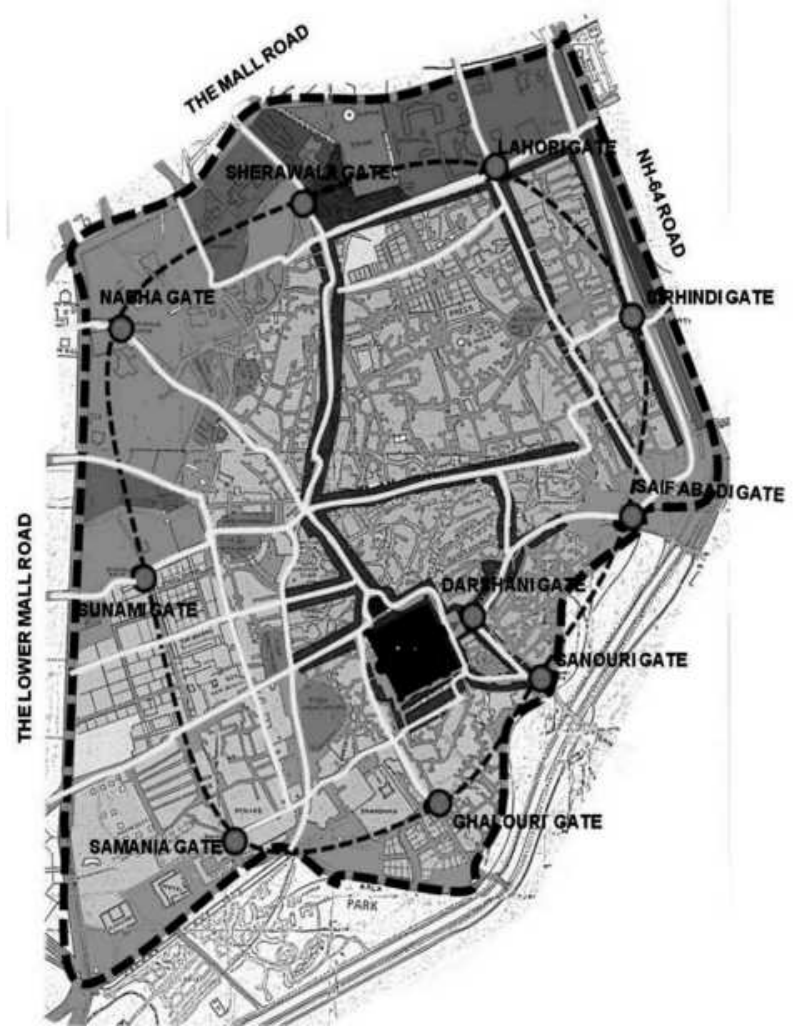

Figure 7. Map showing the walled city of Patiala. (Source: Map taken from Google Earth; Adapted by Author) 


\section{The Mohindra College, Patiala}

\subsection{Historical Background \& Significance}

The philanthropic zeal and generosity of late Maharaja Mohinder Singh laid the foundation of the first degree college, the Mahindra College at Patiala, the famous princely states of former Punjab's Malwa region. It was the only educational institution and one of its kinds between Lahore and Delhi imparting education free of cost. Initially affiliated to the Calcutta University, the college began with imparting Arabic, Sanskrit and Persian education. Mohindra College campus, as it continues to stand today was located just outside the walled city of Patiala. (Fig. 8) The road along the entrance of the college came to be known as the college road over the years. After the advent of education reforms during the British Raj, the college started teaching Mathematics and English soon after its inception (Dhanani B., Aarti, 2012). The education level advanced upto B.A. in 1887 commemorating the reign of Queen Victoria. It further opened Post graduation courses in Mathematics in 1912, and Post graduation in Philosophy in 1922. The economic dip in 1930 brought about nominal fees from the students. The College was affiliated to the Punjabi University, Patiala in 1962. The College Building continues to be used for the same purpose till today for which it was originally designed and built.

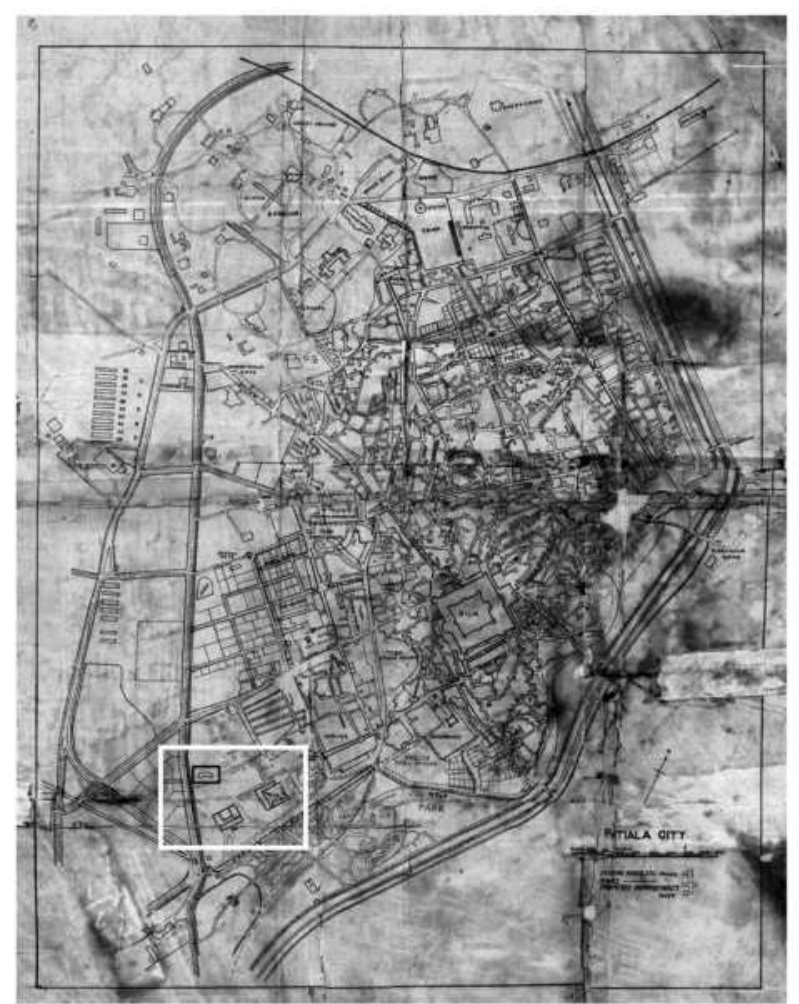

Figure 8. Location of Mohindra College on the Map of Patiala 1922 (Source: Patiala Archives)

\section{Significance of the College}

Set up by Maharaja Mohinder Singh (1852-1876), the Govt. Mohindra College was his most significant contribution which majorly impacted the educational life of the state. Named after the Maharaja's name, it is one of the oldest and leading institutionsof higher learning in North India. It being the first college of its kind between Delhi and Lahore, (Vandal S. H., 2011) was very significant in promoting education and literacy among the common masses. The laying of an educational institution of a scale reflected a progressive social reform by the rulers of the area which significantly contributed in the process of modernization (Manjrekar, N. 2017). The foundation stone of the college was laid way back in 1875 when Patiala was one of the progressive princely states of India (Mehta, M. 1993). In 1958 the Government of India released a one rupee stamp with the photo of Mohindra College on it. (Fig. 9a \& 9b) The college building has rich architectural characteristics of the British Colonial Architecture blended with a classical touch with colonnaded corridor rich in ionic columns mounted by semi-circular arches, entrance portico adorned with a pediment and Corinthian columns, richly decorated cornices, parapets, pilasters, externally adorned with stucco work and huge minarets replicating the Gothic style.
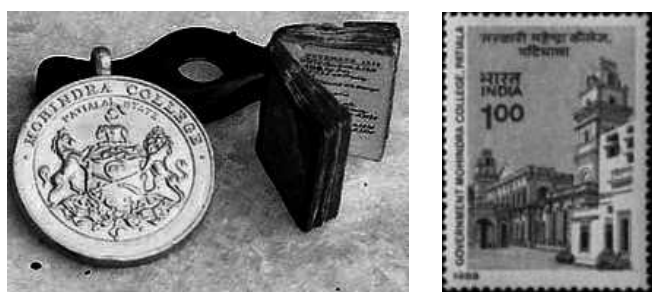

Figure 9a-9b: A gold medal with mention of Mohindra College Patiala (Source: The Tribune, Thursday, July 31, 2003, Chandigarh, India) and the postal stamp of the college released in 1958 by the centre as the college was included in the list of 100 years plus old colleges of the country (Source: http://indiapicks.com/stamps/ Edin/EIC_1302_Mohindra.htm)

\subsection{The context of the site and its surroundings}

The site is located on the Lower Mall Road adjacent to the famous National Institute of Sports including the historical MotiBagh Palace Complex. The site of the Mohindra College is split into two parts with the 21.70 acre main college campus on one side and the 1.85 acres area for swimming pool on the opposite side of the lower mall road. The total site area of the college is 23.55 acres. Originally the site was much bigger and the triangulated corner of the site was a part of the college premises as per the plan of Patiala in 1922 (Patiala Princely State 2017) . But gradually as the times passed by and no one resented, the land was 
encroached by the common masses and an irregular site of the college campus is what exists now. The existing site area of the campus is 21.70 acres.

The land adjacent to the NIS chowk was encroached by people and this land is now occupied by slums Site sources revealed that the land, originally a part of the Mohindra College campus was gradually encroached by people in around mid 20th century. Primary sources revealed that the land was allotted by the Raj Pehalwaan KesarPehalwaan who moved them from the opposite side along the nallah and gave them space here. Since then the area has been occupied by slums and witnessed unauthorised constructions. A Gurudwara which was originally a temple was also said to have been there because of the Pehalwaan's efforts for satisfying his own religious beliefs. The two high towers and the grand scale of the main college building make the building distinctly visible from the adjoining roads. The access to the college campus is from an $8 \mathrm{~m}$ wide road. Opposite the site is a nallah stretching parallel to the boundary of the college with the residential area on the other side. The famous Budha Dal Public School lies adjacent to the site. The site has the lower mall road on one edge and has residential development all around it.

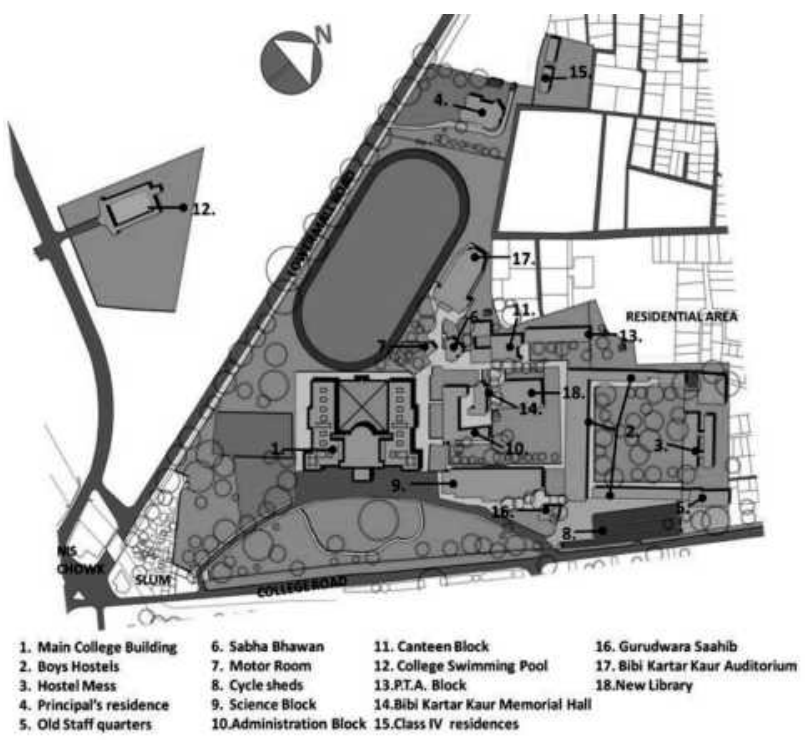

Figure 10. Site Plan showing the site organization of buildings and circulation. (Source: Author)

\subsection{Site organization}

The site is approached by an $8 \mathrm{~m}$ wide road and is irregular. (Fig. 10) The site has three entry gates - two gates towards the front on the south east boundary wall and one gate on the west of the site that leads to the principal's residence. Each street type is defined by the type of traffic it serves, but it is also differentiated by specific surface materials, paving patterns, and lighting. The character of the campus streets is defined by their adjacency to campus buildings, open spaces and services. The vehicular and the pedestrian access are through the main entry gate. The road leads to the car and cycle parking on one side and to the porch of the main building on the other side. The provision of metalled road for vehicular circulation is restricted to the front portion of the site only. The pedestrian connection connects all other parts of the site including the principal's residence which lies on the northern end of the site. The vehicular access is limited to the main building only whereas all other buildings are connected through interlinked walking passages and corridors.

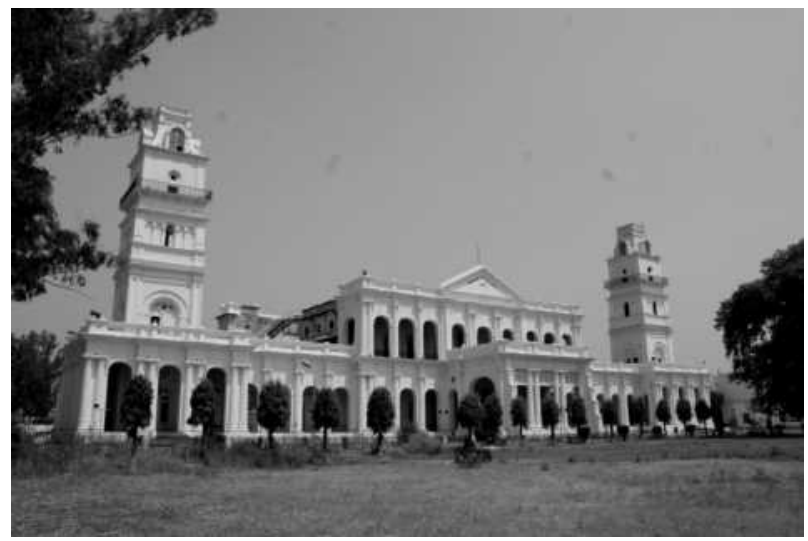

Figure 11. Front façade of the Main College Building (Source: Author)

The site has a number of buildings spread over the entire site interspaced by a number of open spaces. Some buildings like the main building, hostels, the science block face the roadways while others are set back in park like settings and accessed through green spaces. There is no clear organization and this has lead to problems regarding orientation of visitors on campus. Amongst the built structures the most important historic structures that exist on site are the Main College Building, (Fig. 11). The Hostels along with the warden's residence and the principal's residence along with the servant quarters attached to it. All these buildings date their construction back to the late 19th century i.e. 1875 . The architectural characteristics, structural definitions and the courtyard planning concept define their historic significance and a strong association with the past traditions of planning and construction technologies. Out of the total site area of 21.70 acres more than $50 \%$ area is allotted to open spaces. Some open spaces serve to be as meeting places, pedestrian links and horticultural gardens. Typically these areas are heavy-use, heavy traffic areas on maintained gardens. These spaces are the interaction spaces, the green courtyards and the public gardens that are used as spill over spaces by the students and the staff in their free time. 
Part of the open space is used as recreation space having narratives related primarily to exterior areas used for sports activities, social gathering and recreation. The huge football ground and the three basket ball courts enhance the sports activity on the campus. Besides, a large chunk of land is left untreated and has unmaintained vegetation on the site.

\subsection{PlanningPrinciples of the Main College Building}

The plan is a pure square with the boundary wall at the rear end completing the geometry of the form. The plan of the College building is a symmetrical $U$ shaped plan which has its open side on the northwest with a central axis running southeast to northwest. It has a rear courtyard enclosed on three sides.(Fig. 12 a \& 12b) The building is an axial symmetrical plan about a vertical axis. The courtyard on the central axis is an architectural consideration with respect to the climatic conditions of the area. The climate is extremely hot and dry in one part of the year and hot and humid at the other. Courtyard Planning in the building provides a solution to the climatic problem as it performs and functions as a modifier of climate and allows outdoor activities with protection from sun dust and wind. The entry to the building is through a well decorated porch that lies on the central axis on the south-eastern end. The Ground Floor consists of a central hall which originally served as an assembly hall and is now functioning as an art gallery for the Fine Arts Department. The floor plan mainly consists of as many as 24 big rooms all of which were originally used as classrooms laid out symmetrically on both the sides about the central hall. The corner rooms below the tower functioned as the administrative offices. All these classrooms are lined up along the deep arcaded veranda which protects them from the intense summer sun providing for adequate shade inside. The interior of the classrooms have a number of wall openings in the form of doors that are planned opposite to each other to provide for ventilation, recessed windows and high ventilators along with clerestory windows. Most of the rooms were well lit with indirect lighting with good ventilation. The ceilings of the rooms were more than $6 \mathrm{~m}$ high which gave the look of huge spacious room At the two ends are small rooms which serve as the office area. Two staircases symmetrical about the central axis are laid out on the both the sides and lead to the first floor. The First Floor has been built up only partly above the central hall and the adjacent classrooms on both the sides. On the ground floor the horizontal circulation is defined through a continuous corridor all along the building that acts as a deep shade for the rooms aligned along it. The vertical circulation is through the two staircases at the opposite ends leading to the terrace on the first floor. The balcony of the central double height hall is also approached from the terrace on the first floor. The southeast facing building block has a frontage of about $100 \mathrm{~m}$ with porch projecting in the middle and two bays at either end that are slightly projecting, with triangular pediment above the central portion. Corinthian columns support the porch and the corridor along the length of the classrooms. The whole facade has adornments of geometric and floral panels in plasterwork on columns with a classical blend. A variety of architectural elements haven been used in the building like columns and pilasters [ornamented capitals], cornices, pediments, arches, jallies, parapets, etc.
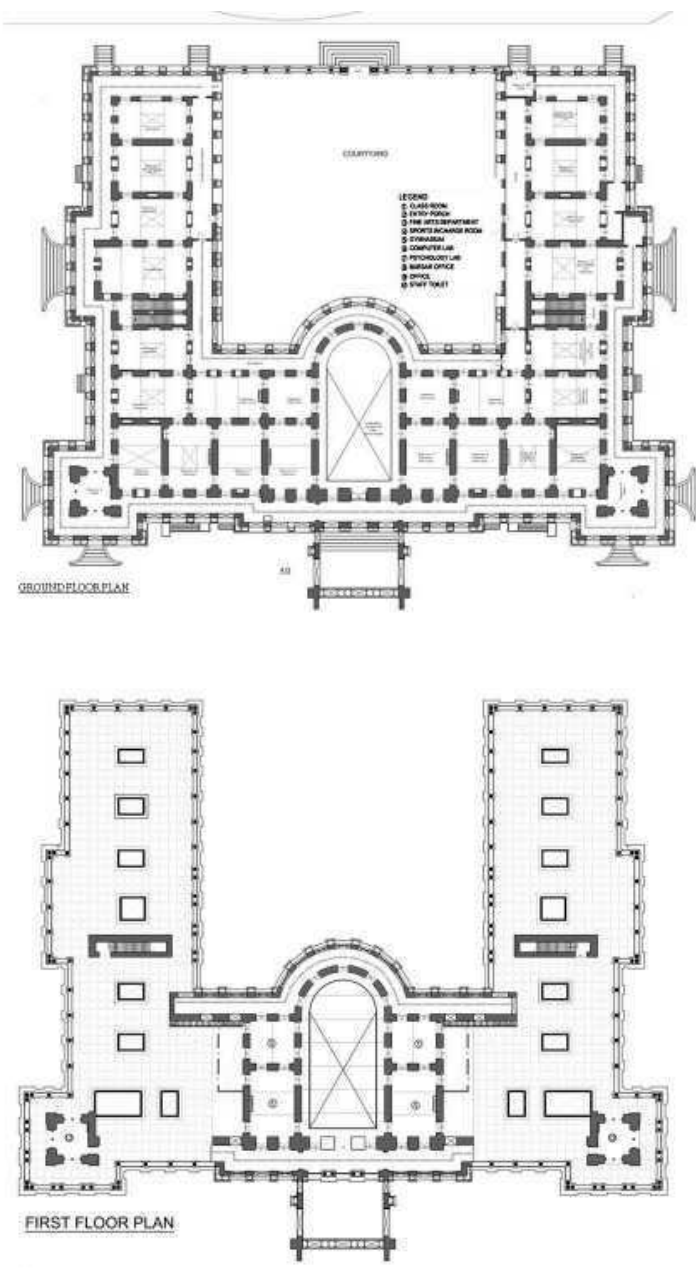

Figure 12a -12b. Ground and First Floor Plan of the Main College Building (Source: Author)

\subsection{Architectural features}

a) Door \& Windows: The doors, windows and ventilator frames are all made up of sheesham wood. The scale of the doors was monumental soaring to a height of $3 \mathrm{~m}$. 
(Fig. 13) The doors have classical style arches and ribbon windows which accentuate the beauty of the façade. All wooden frames have been painted with white enamel paint. The shutters are a combination of wood and glass. Wire mesh / grills have been added later on. The original sash bars and all other members were all fabricated out of wood. Certain doors and windows have wire mesh shutters along with wooden shutters.

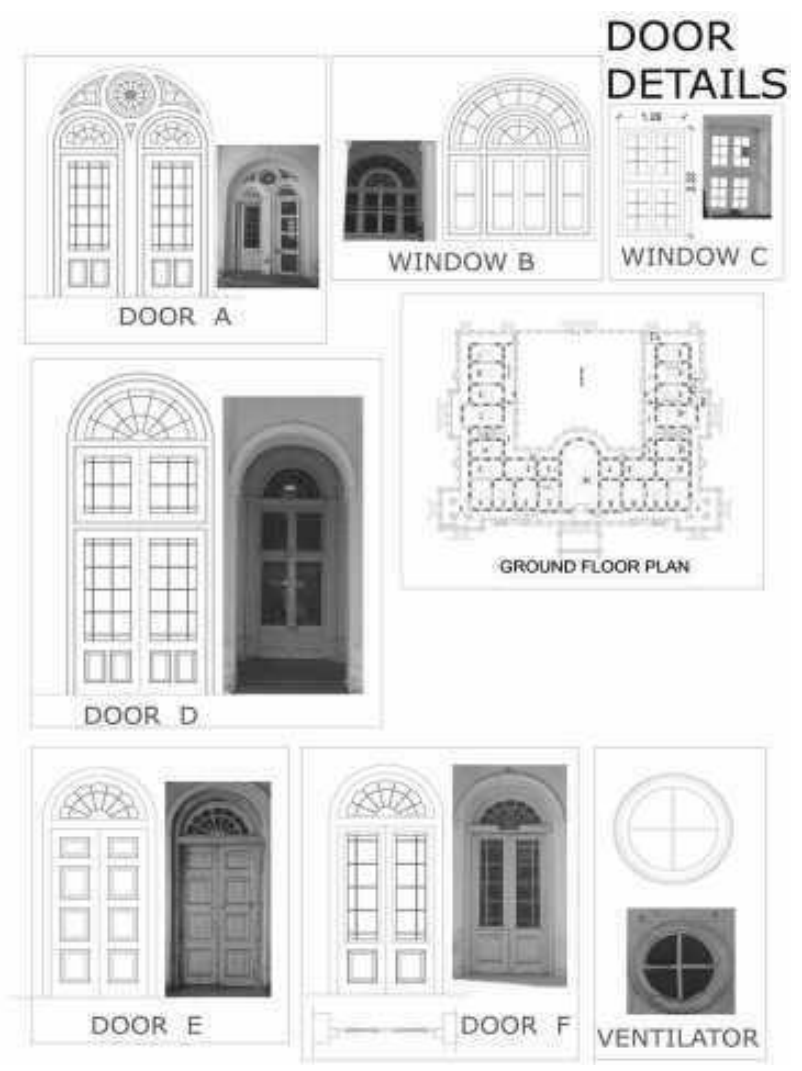

Figure 13. Details of Doors, Windows and Ventilators in the Main College Building (Source: Author)

The precise spacing of doors and windows at short intervals, exactly opposite to each other facilitated cross ventilation through the building. The main rooms had high ceilings with ventilators set at roof levels, so that the rising hot air could escape. These are usually rectangular inside and circular from outside. The panels were not intricately carved. the window sills have recessed and the lintel comprises of a series of arches form a feature of the upper floor, resembling with an arch which is of French style. The frames were fixed to the walls using holdfasts, adapted from the Colonial style.

b) Columns and Pilasters: The three orders - Doric, Ionic and Corinthian or the organizational system of classical architecture have been used in the entire façade as columns and pilasters (Fig. 14). They are in the form of huge brick columns supporting the arches which frame the entire façade of the college building. Pillars serve only the aesthetic purpose except for that in the porch. Structurally they have no role in the building as most of the load is taken by the thick load bearing walls. The Columns in the front porch have the Doric orders (detail B). The pilasters that are along the entire length of the corridor have the ionic order with beautiful volutes (detail A) and the ones on the apsidal end are the (Corinthian pilasters detail C). All the columns and pilasters have been made of bricks with cement mortar and are plaster finished.

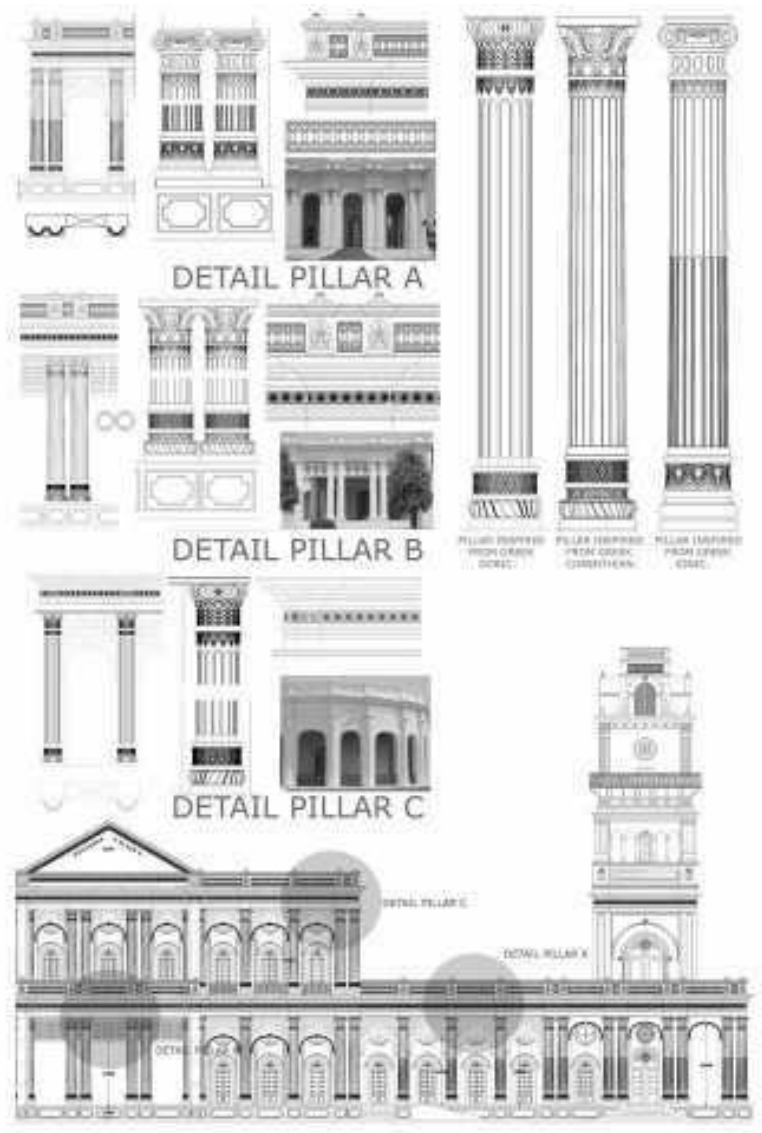

Figure 14. Details of Columns \& Pilaster (Source: Author)

c) Hall: The central hall of about $275 \mathrm{sqm}$ is double height and was originally used as an assembly hall. (Fig.15). The hall has an apsidal end on its shorter side towards the courtyard with a series of arcaded openings. It lies on the main axis and has an approach from the porch on the ground and the $1.2 \mathrm{~m}$ wide projected balconies have their approach from the terrace of the first floor. It has extensively detailed out cornices, railings, balusters and brackets as shown in the figure. The hall has the old 
style battened flooring with the double roofing system, the battens laid over the girders which are typical of the British construction system. Presently the hall is used as a Fine Arts exhibition hall.

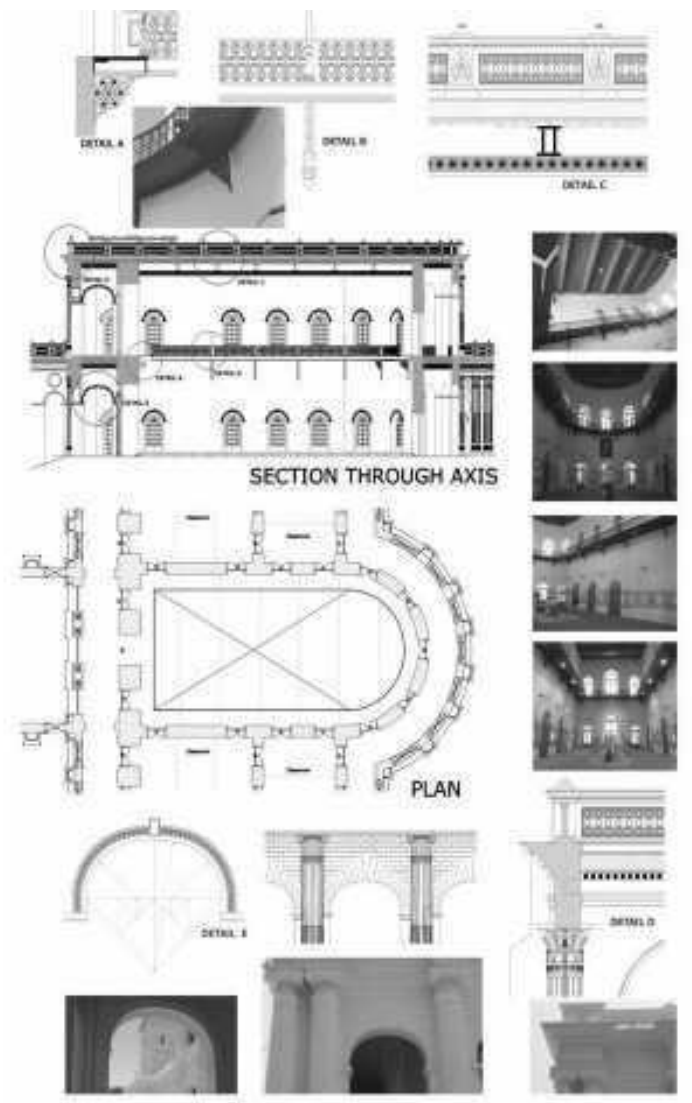

Figure 15. Details of the main Assembly hall inside the College Building (Source: Author)

d) Parapets: The parapet runs through the entire periphery and makes a bold impression with rectangular recesses set within a rectangular frame. The parapets are made of cut bricks in a variety of designs and run throughout the edge of the building with intermittent vertical columns also made of bricks as per details B, C\& D. At some places and in the tower the parapets are made as $900 \mathrm{~mm}$ high cast iron grills as per the details A \& E. The details of the parapet are as per the figure 16 .

e) Towers: The two imposing towers built in the Gothic style are reflective of the stylistic association of the building with the classical style of architecture. The watch tower gives indication of "cathedralization". It houses the staircase as well as functions as watch tower(Fig. 17).

The high soaring tower is approached through the terrace and raises three more storeys above the ground floor. Originally the floors within the tower were approached by a steeply pitched staircase with a rises as high as $375 \mathrm{~mm}$ leading to a rat trap door as shown in the image below. The façade is richly decorated with plaster motifs and delicate iron grills. The tower tapers at the apex into a slender finial with decorative parapets and arcaded openings.

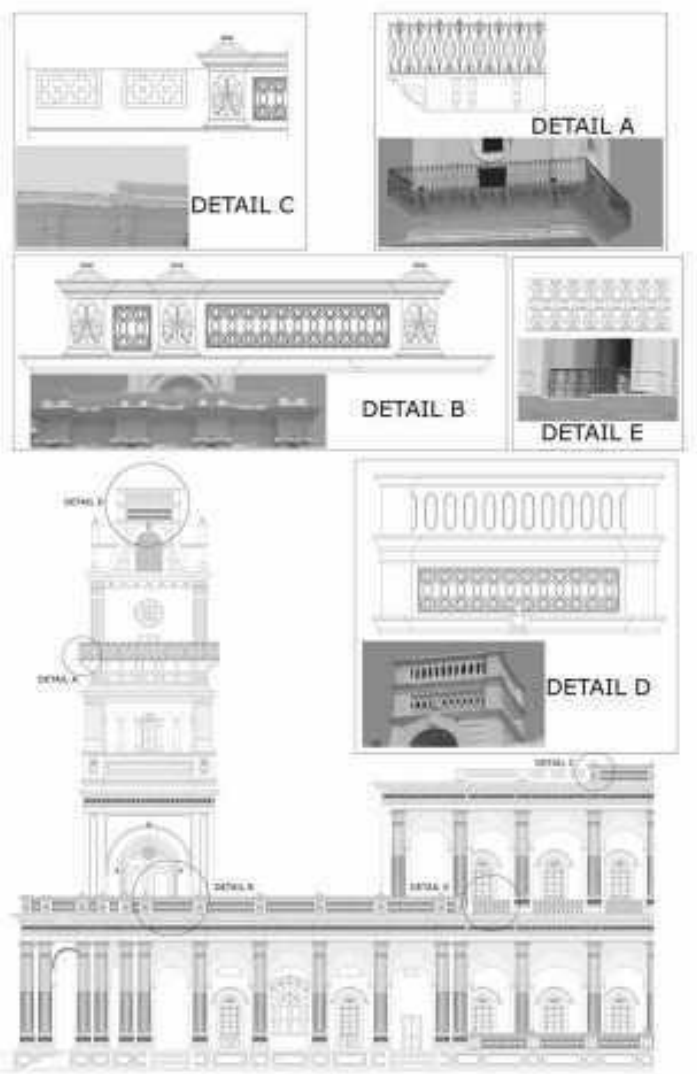

Figure 16. Details of Parapets of the Main College Building (Source: Author)

f) Fireplaces: A typical British feature within the college building is the fireplace in the classrooms. Built in brickwork most of the fireplaces have been removed except for a few. The mantle of the fireplace is supported on two Corinthian style pilasters.

\subsection{Façade Treatments}

The walls are solid brick walls with varying thicknesses of about $.60 \mathrm{~m}-1.10 \mathrm{~m}$. The surface was originally finished with lime plaster. Lately the front façade has been whitewashed while all the other facades have been left untreated and display their original finish. The columns, pilasters and parapets all are made in bricks and lime plastered. Some parapets are cast iron grills also. The main features of the façade are the arches, columns and pilasters, the parapets, the doors, windows and ventilators, the two towers on 
both edge and the main entrance porch. The primary unit is a segmental/semi-circular arch supported on a pair of columns. This element is multiplied, magnified, reduced, exploded and reconstructed in all possible dimensions. The arches are the most distinctive and interesting feature of the college building and show influence of the classical architecture. They are supported on the walls. The segment arch system is typical colonial construction technique. There are also semi circular arches rounded with small radii at places at the door openings mostly. The arch supports 2-3 courses of brick laid vertically with a main central key. The openings forming the doors are also similarly treated and are made visually prominent through the plaster motifs. The balcony on the southeast side of the building comprises of series of arches and columns which are of french style. These have cast iron ornamented railings. Rear and front side balconies differ in their railings design.

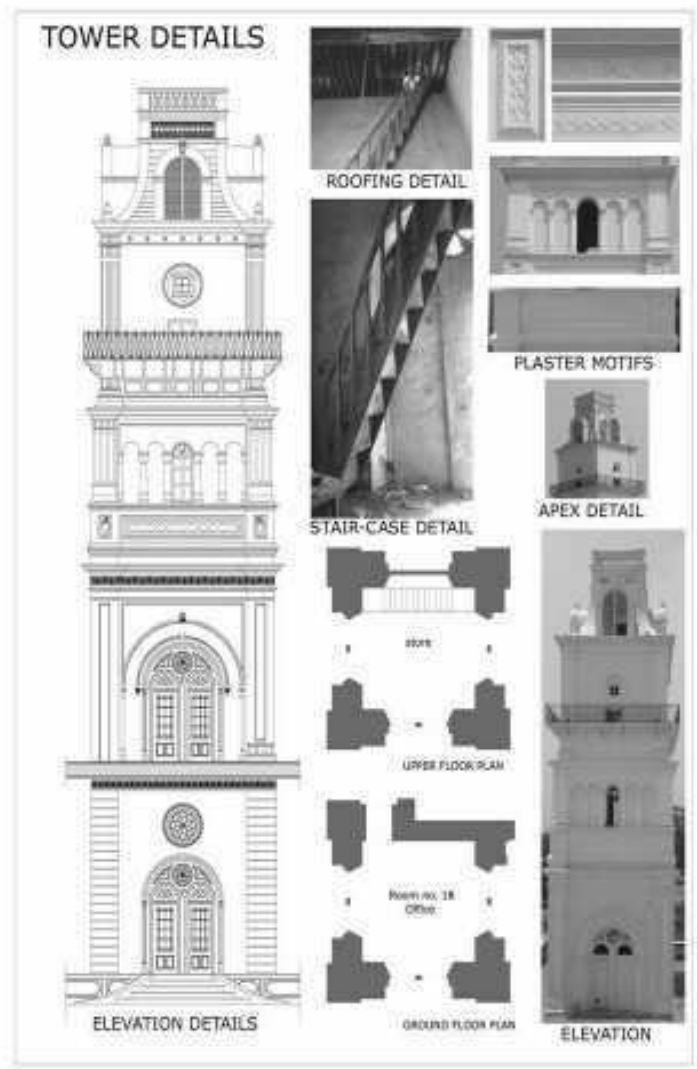

Figure 17. Details of the two identical Towers (Source: Author)

\subsection{Structural Details}

The college building displays a unique architectural style, Saracenic in nature. It is not a column beam structure. The load is transferred through the massive load bearing walls. The greater part of the building was erected in brick and mortar and plastered. The structure or elements of heavier material were scarce. Bricks of size $225 \times 112 \times 75$ were the chief structural material used for construction. The mortar used was mixed with brick, coarse sand and water. A homogenous layer of lime plaster with red pigment covered the brick walls rendering it with an appearance of rich red sand stone. Cast iron elements in the form of girders to support the roof were imported to India from Europe in the 19th century and have been extensively used as roof supporting structural components.

Walls: Indian workers built for the British in the same way as they had built for the invading Mughal princes. The most characteristic feature of the work is brick laying technique which was carried out with great care. Massive walls of brick masonry were built, the basic module being a brick of size $225 \times 112 \times 75$. The mortar used for the masonry mainly consisted of lime. No walls were less than $600 \mathrm{~mm}$ and form the sole load bearing components. Also an additional advantage of the material used for wall construction was its high thermal capacity. The building is finished with plaster that disguises the skeleton The front façade of the wall for the main hall has been so plastered that display the masonry courses. Alternate courses are projected $19 \mathrm{~mm}$ beyond the wall. This breaks the verticality of the walls and directs the eyes horizontally along the length of the corridor.

Roofs: The construction of roofs is typically British in style, which is supported over cast iron girders. The girders taken the load of the battens spaced equally over them successively followed by layers of brick. The roof is flat except for a pediment added as a feature on the front façade of the first floor building. The roof was normally laid in layers above the battens where the brick bats laid in lime constitute the first layer. Mud phuska, the primary purpose of which was for insulation formed the consecutive layer and above this were three courses of bricks that were normally exposed on the first floor terrace. In the class rooms one third of the roof in the room was raised to permit light in the class rooms and acts as ventilation shafts. These clerestory structures were approachable from the terrace on the first floor. The load was taken by the girders supporting the roof structure. The parapets on the roof were made of bricks and are have intricate cut brick jails. Flooring: Brick is used for flooring. The top most layer of the roof of the ground floor comprising of brick bats formed the finished floor of the upper layer. The flooring was not given any formal finish and the bricks were left exposed. The courtyard is also laid in brick work. The stairs were laid in stone finish and the main central hall had wooden battened flooring. The bricks on the terrace are laid in a herringbone pattern while some places have been given a cemented finish above the brickwork. Plaster: Lime or chunam is the main ingredient in the plaster used on the walls. A red pigment was added so as to give a 
look of red sand stone. The overall thickness of the plaster all around the walls is $40 \mathrm{~mm}$. Later, wall is painted yellow and the decorative elements were whitewashed in white colour

\subsection{Condition Assessment}

Incongruous and callous alterations, additions or repairs within the buildings have been done within the building by the college authorities. The continuity of the deep veranda all around the building perimeter was barred by the addition of rooms with lesser height. The architectural characteristics do not match with the existing features damaging the overall visual quality of the building. Multiple layers of cementbased plaster and coats of paint have been used to 'repair' the building. A number of places are seen where a lot of touching has been done with cement. Lot of door openings have been closed from one edge of the wall and the door still remains at the other edge make it a dead door. Some door openings were closed by filling them with brick but the roughness of the plaster showed the signs of arches. Additions like ordinary panelled doors, cluttered electrical cables, rainwater pipes (causing seepage) in the exterior etc. marred the aesthetics of such a significant cultural property. Originally, the roofs of the college building were of timber joists and rafters (girders) which had deteriorated due to seepage and termites in the absence of proper maintenance. In the name of repair and renovation, most of the room's wooden ceilings have been replaced by R.C.C. The clerestory windows that acted as source of light and ventilation in the classroom have R.C.C slab laid at the roof level leaving some of the rooms dark and dingy without light.

Incompatible use of cement based plaster in the repair work can be seen both in interiors as well as exteriors. The original plaster had decayed and so the walls have been repaired with cement plaster. The places where the plaster has chipped off, the exposed bricks are visible. These bricks are in good shape and size. Also since the roof of the back side rooms have been replaced with RCC roofs, the same has resulted in hair-line cracks in the plaster at the roof level due to improper bonding between Brick wall and the RCC roof.

\section{Conclusion}

The system of education in India has gone through many changes and developments primarily during the British era before the Indian independence[14]. Education reforms during this time continue to be in place in the contemporary system of education. It is evident that these reforms abolished many social ills and spread education among the common public to make them aware of their powers and rights. Within the state of Punjab, the contribution of the British Raj to the field of education has been noteworthy especially education for the public which promoted the setting up of various symbols of education i.e. educational institutions in Punjab and throughout the country (Essays, UK. November 2013). The development of these structures has remarkably contributed in the economic and social modernization and democratisation process in the 20th century. Literacy policies and awareness spread by the rulers of the Princely States have been the most important tools that are responsible in bringing about the change[13]. Thus the educated royals became agents for bringing about irreversible social, cultural and economic changes.

\section{References}

[1] Bidwaikar, S. (1813). Evaluating the Idea of Education in Colonial India: British and Indian Perspective. (pp. 35-40). New Race 12(4). (2017 September 19) Retrieved from https://pingpdf.com/pdf-british-andindian-perspectives-sri-aurobindo-centre-for.html

[2] Calcutta Madrasa, The. (2017 September 19) Retrieved from http://en.banglapedia.org/index. php?title=Calcutta_Madrasa,_The

[3] Cox, J. (2009). Missionary Education and Empire in Late Colonial India, 1860-1920. Victorian Studies. 51(4). (2017 September 19)Retrieved from https:// muse.jhu.edu/article/366939/pdf

[4] Dhanani B., Aarti, (2012). Princes, diwans and merchants: education and reform in colonial India. (Dissertation) The University of Texas at Austin. (2017 September 19) Retrieved from http://hdl.handle. net $/ 2152 / 25108$

[5] Essays, UK. (November 2013). The British Colonialism And Education In India History Essay. (2017 September 19) Retrieved from https://www. ukessays.com/essays/history/the-british-colonialismand-education-in-india-history-essay.php?vref $=1$

[6] Geddes P., (1973). Town Planning in Patiala State and City: A Report to H.H. the Maharaja of Patiala. Perry's Printing Press.

[7] Manjrekar, N. (2017). Education in the "Sanskarnagari": Baroda, Provincial Capital of a 'Progressive' Princely State in the Late Nineteenth and Early Twentieth Century. In Pink T. W., Noblit G. W., (Ed.) Second International Handbook of Urban Education. (pp. 369-395). Springer.doi : 10.1007/978-3-319-40317-5

[8] Mehta, M. (1993). Princely ruler as an agent of change: A study of Maharaja Sayajirao Gaekwad's policies towards untouchability, 1882-1915. Proceedings of the Indian History Congress. 54, 403-408.

[9] Patiala (Princely State). (2017 September 19)Retrieved from http://members.iinet.net.au/ $\sim$ royalty/ips/p/patiala. html 
[10] Punjab State Gazetteers (1904). Punjab State Gazetteers Vol. XVIII A. (pp.176-180, 46-56). Lahore. Punjab Govt. Press. (2017 September 20) Retrieved from https://dspace.gipe.ac.in/xmlui/handle/10973/33521

[11] Punjab Govt. Lahore. (1909), Punjab State Gazetteers Vol Xvii A Phulkian States, Patiala Jind And Nabha With Maps (1904). Lahore. Punjab Govt. Press

[12] Priyadarshini S. (n.d.) Contribution and Impact of British Rule on India. (2017 September 19)Retrieved from http://www.historydiscussion.net/british-india/ contribution-and-impact-of-british-rule-on-india/2617
[13] Relations with Princely States. (2017 September 19) Retrieved from https://www.tutorialspoint.com/modern indian_history/modern_indian_history_relations_with_ princely_states.htm

[14] Starrett G., (1998) Putting Islam to Work: Education, Politics, and Religious Transformation in Egypt (Comparative Studies on Muslim Societies).University of California Press.

[15] Vandal S. H., (2011). Cultural expressions of South Punjab. Lahore. UNESCO 


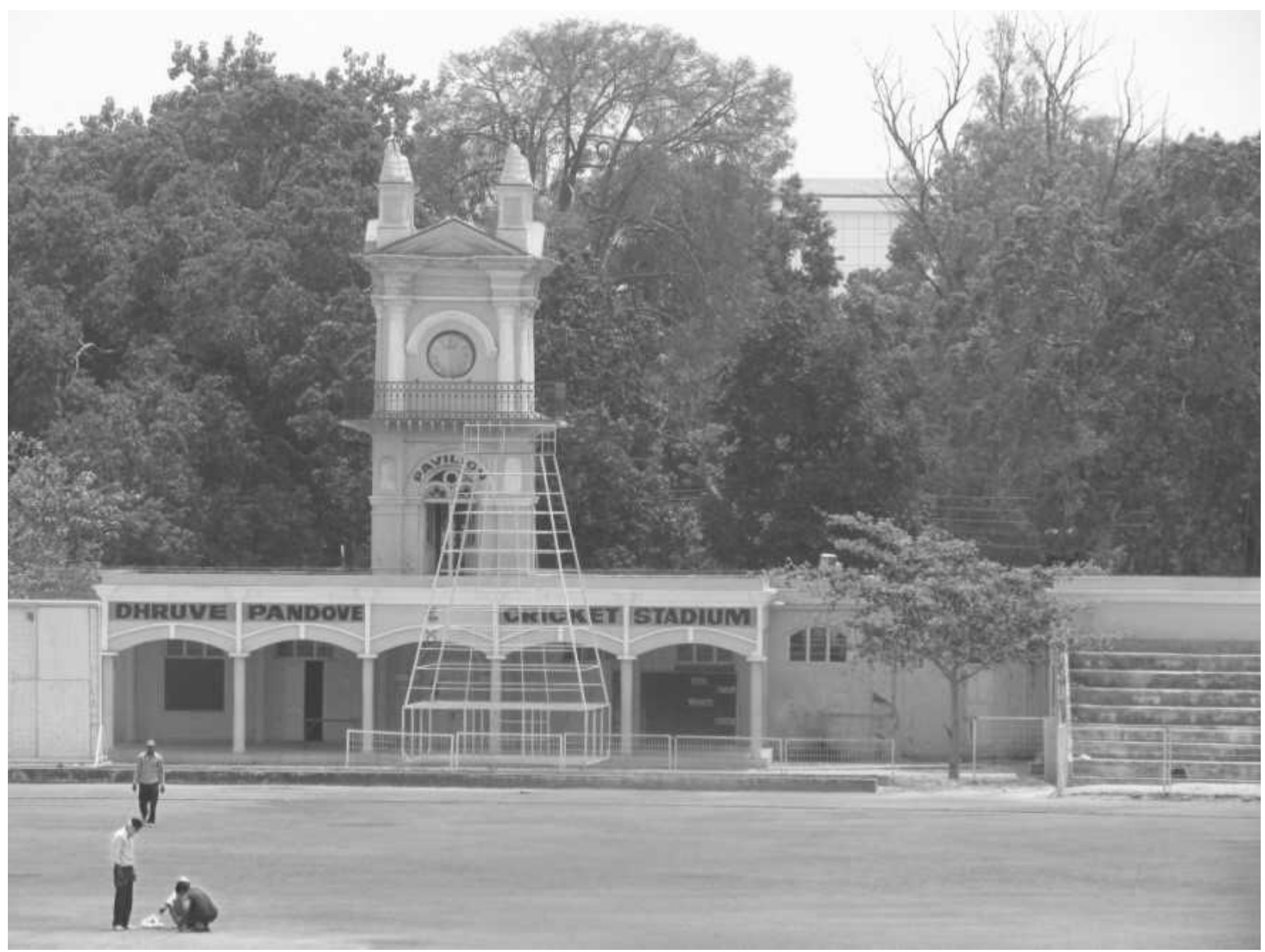

